\title{
COMPARISON OF MAXILLARY OCCLUSAL PLANE WITH VARIOUS CRANIOFACIAL REFERENCE LINES IN NEPALESE AND INDIAN YOUNG ADULTS
}

\author{
Dr. Binod Acharya \\ Professor \& Head; Dept. of Prosthodontics, Kantipur Dental College, Kathmandu
}

E-mail: drbins@hotmail.com

\section{ABSTRACT}

Orientation of occlusal plane for complete dentures play a vital role as it affects all the basic requirements of complete dentures. Depending on soft tissue landmarks for orienting occlusal plane seems to be unreliable. Cephalometrics were introduced in Prosthodontics to orient the occlusal plane in the same position as it was with the lost natural teeth.

In the present study, 60 lateral cephalometric radiographs of a group of male and female dentulous subjects of Indian and Nepali origin (30 subjects in each group) were obtained and tracings were made. All the subjects selected were in the age group of 20-30 years in whom the facial growth was completed. Angular measurements were made between FH (Frankfort Horizontal plane)CP (Camper's Plane), FH-OP (Occlusal Plane) and CP-OP and subjected to statistical analysis to determine the degree of separation between these planes in Indian and Nepalese ethnic groups.

The absolute parallelism between the natural occlusal plane and Camper's plane were not proven in both Indian and Nepalese subjects involved in this study. This significantly reduces the reference values of these planes in Prosthodontics.

\section{INTRODUCTION}

Complete dentures mainly restore the function of mastication along with esthetics and other functions. Though the retention of complete denture is one of the main concerns for the patient; it is the stability of complete denture during the functions that matter more to the operator. Various factors that affect the stability of complete denture are: the proper location and arrangement of the artificial teeth, the size and form of the basal seat, the quality of the final impressions and so on. Amongst these factors the orientation or inclination of plane of occlusion is under operator's control. However, establishment of the optimum level and inclination of the occlusal plane poses a dilemma in an edentulous mouth in the absence of definite guidelines. Besides stability, optimum level and inclination of the occlusal plane play important role in biomechanics of craniomaxillary morphology. According to contemporary concepts, the position of the occlusal plane in the denture wearers should be as close as possible to the position which was previously occupied by the occlusal plane of the natural teeth. There is a lot of evidence that such a position of the occlusal plane enhances denture stability and functional value. The reconstruction of the 'natural level' of the occlusal plane in the edentulous mouth enables the normal function of cheek and tongue muscles and other surrounding structures. 1, 2, 3, 4

Although clinical application of cephalometry has been directed largely towards Orthodontics, it is of special value to Prosthodontics in that it can be used to re-establish the spatial position of lost structures such as the teeth. This is achieved by identifying predictable relationships between the teeth and other cranial landmarks that are not subject to post-extraction changes. The Prosthodontic significance of variations in the upper face has not been investigated for an ethnic Nepalese population.

\section{OBJECTIVE}

To evaluate the inclination of maxillary occlusal plane with reference to Frankfort Horizontal plane (orbitale-porion) \& 
Camper's plane (ala-porion) for Nepalese \& Indian young adults separately. And; to correlate the degree of separation in Frankfort Horizontal Plane, Camper's Plane and Occlusal Plane in two different ethnic groups with the help of cephalometry.

\section{MATERIALS AND METHOD}

The study was carried out on 60 lateral cephalometric radiographs in a group of male and female subjects of Indian and Nepali origin (30 subjects in each group). Among 30 Nepalese subjects, 21 were male and 9 were female; while among 30 Indian samples, 23 were male and 7 were female. Subjects were selected based on inclusion criteria. The subjects were in a age group of 20-30 years in whom the facial growth has completed, presence of full complement of teeth with or without third molars, had ideal dental arch form and alignment, stable centric occlusion with Angle's Class I relationship, with no previous history of orthodontic treatment, with no malocclusion and gross restorations. All subjects were instructed to remove jewelries (ear rings etc) from head region to avoid artifacts in identifying the landmarks. Subject's head was positioned in the cephalostat with the Frankfurt Horizontal Plane parallel to the floor. The subjects were asked to avoid motion during the exposure. The radiographs were taken with teeth in intercuspal position. The film exposure and developing were standardized for every patient. The cephalograms were traced on acetate paper using $\mathrm{x}$-ray viewing box. The tracing was performed by the principal investigator and an Orthodontist to minimize tracing error (Examiner A \& B). Cephalometric tracing were to depict the angles between FH-CP, FH-OP \& CP-OP (Figure $1 \& 2$ ).
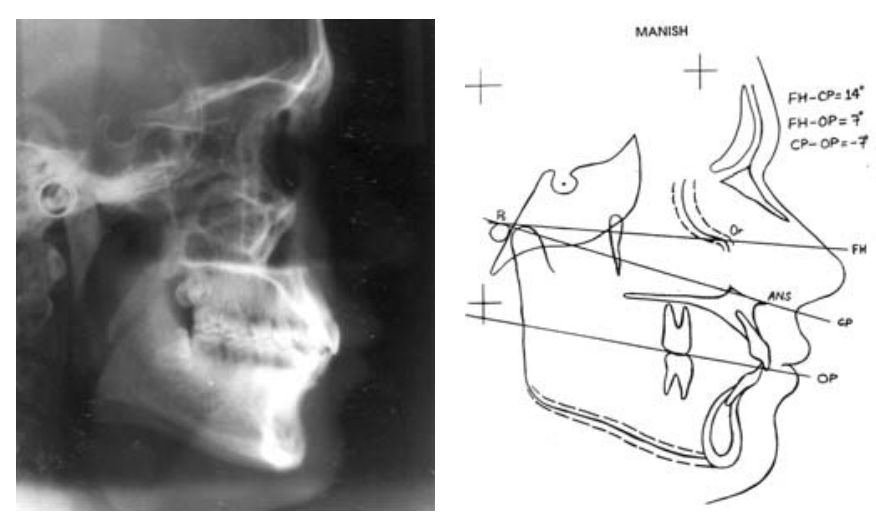

Figure 1 \& 2: Cephalogram and Cephalometric tracing showing the angles between $\mathrm{FH}-\mathrm{CP}, \mathrm{FH}-\mathrm{OP} \& \mathrm{CP}-\mathrm{OP}$

\section{RESULTS}

The descriptive statistics of the parameters studied by the Examiner A \& B are shown in Table 1 and analysis of the statistical difference is shown in Table 2. Examiner A and $\mathrm{B}$ were compared by student's paired t-test. According to this test, there was no statistical significant difference between the examiners. In Indian population, among all three parameters (FH-CP, FH-OP \& CP-OP) at $5 \%$ level of significance $(p>0.05)$ was observed. Similarly in Nepalese population, there was no statistical difference between both the examiners in all three parameters (FH-CP, FH-OP \& $\mathrm{CP}-\mathrm{OP})$ at $5 \%$ level of significance $(\mathrm{p}>0.05)$ as shown in Table 2.

\section{Table 1: Summary of statistics of Indian and Nepalese population}

\begin{tabular}{|c|c|c|c|c|c|c|c|}
\hline \multirow{2}{*}{ Population } & \multirow{2}{*}{ Parameter } & \multicolumn{3}{|c|}{ Examiner A } & \multicolumn{3}{|c|}{ Examiner B } \\
\hline & & Mean & SD & CV & Mean & SD & CV \\
\hline \multirow[t]{3}{*}{ Indian } & $\mathrm{FH}-\mathrm{CP}$ & 13.4333 & 1.8417 & $13.71 \%$ & 13.4167 & 1.7225 & $12.84 \%$ \\
\hline & $\mathrm{FH}-\mathrm{OP}$ & .1667 & .5116 & $.24 \%$ & .2167 & .3245 & $.63 \%$ \\
\hline & $\mathrm{CP}-\mathrm{OP}$ & .5167 & .6613 & $.37 \%$ & .5167 & .463 & $.67 \%$ \\
\hline \multirow[t]{3}{*}{ Nepalese } & $\mathrm{FH}-\mathrm{CP}$ & 14.9167 & 2.0930 & $14.03 \%$ & 14.9000 & 2.0984 & $14.08 \%$ \\
\hline & $\mathrm{FH}-\mathrm{OP}$ & .6333 & .7369 & $.95 \%$ & .7333 & .5251 & $.58 \%$ \\
\hline & $\mathrm{CP}-\mathrm{OP}$ & .1667 & .5875 & $.1053 \%$ & .1500 & .3713 & $.17 \%$ \\
\hline
\end{tabular}




\begin{tabular}{|c|c|c|c|c|c|c|c|c|}
\hline Parameter & Population & Examiner & Mean & SD & $\begin{array}{l}\text { Difference } \\
\text { in mean }\end{array}$ & $\begin{array}{l}\text { Paired } \\
\text { t- value }\end{array}$ & p-value & Significance \\
\hline & \multirow[t]{2}{*}{ Indian } & $A$ & 13.4333 & 1.8417 & \multirow[t]{2}{*}{0.0167} & \multirow[t]{2}{*}{0.2541} & \multirow[t]{2}{*}{$>0.05$} & \multirow[t]{2}{*}{ NS } \\
\hline & & B & .4167 & .7225 & & & & \\
\hline & \multirow[t]{2}{*}{ Nepalese } & $A$ & 14.9167 & 2.0930 & \multirow[t]{2}{*}{0.0167} & \multirow[t]{2}{*}{0.4412} & \multirow[t]{2}{*}{$>0.05$} & \multirow[t]{2}{*}{ NS } \\
\hline & & B & .9000 & .0984 & & & & \\
\hline & \multirow[t]{2}{*}{ Indian } & $A$ & 8.1667 & 4.5116 & \multirow[t]{2}{*}{-0.05} & \multirow[t]{2}{*}{-0.5935} & \multirow[t]{2}{*}{$>0.05$} & \multirow[t]{2}{*}{ NS } \\
\hline & & B & .2167 & .3242 & & & & \\
\hline & \multirow[t]{2}{*}{ Nepalese } & A & 7.6333 & 3.7369 & \multirow[t]{2}{*}{-0.1333} & \multirow[t]{2}{*}{-1.4899} & \multirow[t]{2}{*}{$>0.05$} & \multirow[t]{2}{*}{ NS } \\
\hline & & B & .7333 & .5251 & & & & \\
\hline & \multirow[t]{2}{*}{ Indian } & $A$ & -5.5167 & 3.6613 & \multirow[t]{2}{*}{0} & \multirow[t]{4}{*}{0} & \multirow[t]{2}{*}{$>0.05$} & \multirow[t]{2}{*}{ NS } \\
\hline & & B & .5167 & .4633 & & & & \\
\hline & \multirow[t]{2}{*}{ Nepalese } & $A$ & 7.16667 & 2.5876 & \multirow[t]{2}{*}{-0.0167} & & \multirow[t]{2}{*}{$>0.05$} & \multirow[t]{2}{*}{ NS } \\
\hline & & B & .1500 & .3713 & & & & \\
\hline
\end{tabular}

\section{DISCUSSION}

According to Boucher, "If the soft tissues surrounding the dentures are to function as they did for natural teeth, the occlusal plane should be oriented exactly as it was when the natural teeth were present. However, to locate an occlusal plane high or low to favor the weaker of the two ridges can cause both esthetics and mechanical trouble." It becomes questionable how to discover which position was occupied by the 'natural occlusal plane' after the loss of the natural teeth.

Many studies have been conducted in the past to locate the 'lost occlusal plane' $i$ in edentulous patients considering Camper's plane. Similarly, in cephalometric studies the upper border of the porion, $1,6,7$ the middle of the porion ${ }^{8,9}$ and the lower border of the porion ${ }^{10,11}$ have been used as the posterior reference point of Camper's plane. In majority of these cases, Camper's plane connects the anterior nasal spine with the superior border of porion. Further, there is much controversy concerning the coincidence of Camper's plane defined radiographically and ala-tragus line defined by skin points. Some advocates of the ala-tragus line never mention Camper's plane, ${ }^{12}$ other consider the two to be the same, ${ }^{13,14,15}$ and still others make a clear distinction between Camper's plane and the ala-tragus line..$^{11,16}$

Thus, it is obvious that to re-establish the occlusal plane in edentulous patients, it is desired to obtain certain craniofacial reference planes so as to relate it to the occlusal plane. It has been pointed out by many authors that the level and inclination of occlusal plane varies with respect to different skeletal configurations. ${ }^{8}, 17$ Study conducted by Patil NP and Sachdev H18 in 1998 suggest that, there is difference in inclination of occlusal plane with respect to various skeletal jaw relationship in Indian population. European studies ${ }^{19}$ have indicated comparable mean angular values across the samples measured between Frankfort horizontal line (orbitalporion) and reference lines such as Camper's line (ala-porion). According to Ow RKK et $\mathrm{a}^{17,16,19}$ and Cooke MS et al ${ }^{20}$ there is certain variations in Chinese and British Caucasian population in occlusal plane and the various craniofacial reference planes like Frankfort horizontal plane and Camper's plane. Ethnic and racial variability in various anatomic landmarks causes differences in the norms established for specific groups. ${ }^{7,16}$ Cephalometric studies have been chosen as a method of investigation to examine the possibility of ethnic variations in cranial reference planes, since other methods are not very reliable.

The absolute parallelism between the natural occlusal plane \& Camper's plane has not been proven either in Indian or Nepalese subjects involved in this study. This significantly reduces the reference values of these planes in Prosthodontics. The inclination of maxillary occlusal plane exhibited a significantly shallower cant for Nepalese in comparison with 
Indians. This was indicated by the larger negative mean CPOP angle \& consequently mathematically smaller angle by $1.65^{\circ}$ for Nepalese population, which means maxillary occlusal plane in Nepalese slopes down more caudally by $1.65^{\circ}$ than in Indian population. There was a statistical significant difference in mean angulations of FH-CP between Indian \& Nepalese population at $1 \%$ level of significance. This suggested that ethnic differences in the facial skeleton, especially in upper face, many account for the increased mean angular values obtained for the Nepalese compared to Indian samples.

\section{CONCLUSION}

Based on the findings of the present study it may be stated that the reliability of Camper's plane as a guideline to simulate the natural occlusal plane in Prosthodontics is questionable and should be regarded as independent anthropometric entities.

\section{REFERENCES}

1 Hickey JC, Zarb GA. Boucher's Prosthodontic Treatment for Edentulous Patients. 8th ed, St. Louis. C.V. Mosby Co., 1980, pp 296, 348-350.

2 Landa JC. A scientific approach to the study of the temporomandibular joint and its relation to occlusal disharmonies. J Prosthet Dent 1957; 7: 170 .

3 Lundquist DO, Wallance WH. Occlusal plane determination. J Prosthet Dent 1970; 23: 489-498.

4 Yasaki M. Height of the occlusion rim and the interocclusal distance. J Prosthet Dent 1961; 11:26.

5 Hickey JC, Zarb GA, Bolender CL. Boucher's Prosthodontic Treatment for Edentulous Patients. 9th ed. CBS Publishers and Distributors, 1990, pp 355-356.

5 Olsson A, Posselt U. Relationship of various skull reference lines. J Prosthet Dent 1961; 11: 1045-1049.

6 Ow RKK, Djeng SK, Ho CK. The relationship of upper facial proportions and the plane of occlusion to the anatomic reference planes. J Prosthet Dent 1989; 61: 727-733.

7 Augsburger RH. Occlusal plane relation to facial type. J Prosthet Dent 1953; 3: 755-770.

8 The Academy of Prosthodontics. The Glossary of Prosthodontic Terms, 7th ed., J Prosthet Dent 1999; 81: 41-126.

9 Karkazis HC. Relationship between ala-tragus line and natural occlusal plane- Implications in denture prosthodontics. Quintessance Int., 1986; 17: 253-255.

10 Sinobad D, Postic SD. Roentgenocraniometric indicators of the position of the occlusal plane in natural and artificial dentitions. Eur J Prosthodont Rest Dent, 1996; 4: 169-174.

11 Williams DR. Occlusal plane orientation in complete dentures construction. J Dent, 1982; 10: 311-316.

12 D'Souza NL, Bhargava K. A cephalometric study comparing the occlusal plane in dentulous and edentulous subjects in relation to the maxillomandibular space. J Prosthet Dent, 1996; 75: 177-182.

13 Niekerk van FW, Miller VJ, Bibby RE. The ala-tragus line in complete denture prosthodontics. J Prosthet Dent, 1985; 53: 67-69.

14 Ogawa T, Koyana K, Suetsugu T. The relationship between inclination of the occlusal plane and jaw closing path. J Prosthet Dent, 1996; 76: 576580.

15 Ow RKK, Djeng SK, Ho CK. Orientation of the plane of occlusion. J Prosthet Dent, 1990; 64: 31-36.

16 Hartono R. The occlusal plane in relation to facial types. J Prosthet Dent, 1967; 17: 549-558.

17 Patil NP, Sachdev H. A cephalometric investigation into the validity of the correlation between the natural occlusal plane and skeletal and soft tissue landmarks in young Indian adults with different skeletal jaw relationships. M.D.S. thesis, 1998; Karnataka University.

18 Ow RKK et al. A radiographic interpretation of craniofacial reference lines in relation to prosthodontic plane orientation. Aust Dent Journal, 1986; 31: 326-334.

19 Cooke MS, Wei SHY. A comparative study of Southern Chinese and British Caucasian cephalometric standards. Angle Orthodontist, 1996; 59: 131-138. 